\title{
The Transmission of Federal Reserve Tapering News to Emerging Financial Markets*
}

\author{
Joshua Aizenman, ${ }^{\mathrm{a}}$ Mahir Binici, ${ }^{\mathrm{b}}$ and Michael M. Hutchison ${ }^{\mathrm{c}}$ \\ ${ }^{a}$ University of Southern California and NBER \\ ${ }^{\mathrm{b}}$ Central Bank of Turkey \\ ${ }^{\mathrm{c}}$ University of California, Santa Cruz
}

\begin{abstract}
This paper evaluates the impact of tapering "news" announcements by Federal Reserve senior policymakers on financial markets in emerging economies. We apply a panel framework using daily data, and find that emerging-market asset prices respond most to statements by Federal Reserve Chairman Bernanke, and much less to other Federal Reserve officials. We group emerging markets into those with "robust" fundamentals (current account surpluses, high international reserves, and low external debt) and those with "fragile" fundamentals and, intriguingly, find that the exchange rates of the robust group (and, to a lesser extent, equity prices and CDS spreads) were more adversely affected by tapering news than the fragile group. The cumulative effects of tapering announcements after a month, however, appear to be quite similar for both robust and fragile emerging markets.

We also show that more financially developed economies are more affected by tapering news, and a plausible interpretation is that more financially developed economies are more exposed, at least in the short term, to external news announcements.
\end{abstract}

JEL Codes: F3, F36, G14.

${ }^{*}$ We thank the editor of this journal and three anonymous referees for very helpful suggestions on an earlier draft of this paper. Author e-mails: aizenman@usc.edu; mahir.binici@tcmb.gov.tr; and hutch@ucsc.edu. 


\section{Introduction}

The quantitative easing (QE) policies of the U.S. Federal Reserve in the years following the crisis of 2008-9 included monthly securities purchases of long-term Treasury bonds and mortgage-backed securities totaling $\$ 85$ billion in 2013 . The cumulative outcome of these policies has been the unprecedented increase of the monetary base, mitigating the deflationary pressure of the crisis. The resultant lower interest rates and flattened yield curve improved financial conditions and helped stimulate real economic activity, yet the QE policy raised pertinent questions regarding the timing and the nature of the exit strategy (Williams 2011, 2012). These issues came to the fore in 2013, with vigorous and intensifying debate among policymakers and market participants about the exit strategy from the massive monetary stimulus. The growing frequency of public statements by the Federal Reserve's governors and presidents, combined with occasional press releases, have been the focus of the financial media, changing expectations and moving market prices. This process culminated on December 18, 2013, when the Federal Reserve decided at the Federal Open Market Committee (FOMC) meeting (as announced in the public statement) to taper its quantitative easing policy by $\$ 10$ billion per month, to $\$ 75$ billion. Chairman Bernanke also projected the program to wind down steadily through 2014 and conclude by year-end, assuming the economy remained healthy. Subsequent announcements gave news of a gradually reduced QE, and the pattern continued after the appointment of Chair Yellen.

An important feature of quantitative easing and unprecedentedly low U.S. interest rates is that it led to large short-term capital inflows to a number of emerging markets, which in turn led several to impose capital controls, such as Brazil, Indonesia, South Korea, and others (Ahmed and Zlate 2013). Quantitative easing led the U.S. dollar to be the funding currency in large-scale carry-trade activity with emerging markets as the target currencies. The concern with tapering is the flip side: potentially disruptive large-scale capital outflows from emerging markets as carry-trade activity is unwound in expectation of tapering (and, eventually, reduction in the Federal Reserve balance sheet through sales of assets, not just reduction in the pace of purchases) and hints at future interest rate increases. 
Large capital outflows could create disruptions in financial markets and eventually real economic activity in emerging markets.

This paper evaluates whether tapering announcements have disrupted financial markets in emerging economies. We investigate the impact of tapering "news" announcements by Federal Reserve senior policymakers on financial asset prices in emerging markets. The emerging markets' financial asset prices of interest are national stock markets, exchange rates, and credit default swaps (CDS) spreads. These reflect a broad spectrum of the potential effects of tapering, where we would expect greater likelihood of tapering, and hence capital outflows, from emerging markets, to cause a fall in equity markets, depreciation of exchange rates, and an increase in CDS spreads (reflecting greater uncertainty and risk in sovereign bond markets). In terms of Federal Reserve "news," we focus on statements from Federal Reserve Chairman Bernanke, Federal Reserve Board governors, and Federal Reserve Bank presidents, as well as FOMC statements and minutes. Our presumption is that it is important to differentiate between announcements/statements by the Chair, who is the public face and most important Federal Reserve policymaker, and other Federal Reserve policymakers (governors and presidents).

We employ daily data during November 2012 and October 2013. Statements about the likelihood of future tapering, or scaling back the large-scale asset purchase program (LSAP), began to emerge in late 2012, marking the beginning of our sample period. However, during this period there were also frequent and forceful statements by Federal Reserve officials about the need to continue quantitative easing, so these statements were also included as "news" in our investigation both to address issues of symmetry and to judge market impacts.

The methodology of the paper is a quasi-event study, akin to Dooley and Hutchison (2009), tracing the impact of evolving narrative about the expectation of future tapering, as revealed to the public through the news media, on key emerging-market prices. We use a panel fixed-effect framework using daily data with a variety of models to evaluate the impact of "news" on the three assets prices (stock market, exchange rate, and CDS spreads). Moreover, we explore whether market responses to tapering "news" are different across emerging markets, perhaps differentiated by the relative strength of their economic fundamentals. In particular, we exploit 
the heterogeneity among the emerging markets, evaluating the association between asset price movements and key characteristics associated with "fragility" or "robustness" of a country, where these characteristics are defined by their current account, international reserve, and foreign indebtedness positions.

Previewing results, we find that emerging-market asset prices respond most to statements by Federal Reserve Chairman Bernanke, and much less to the frequent, divergent, and sometimes inconsistent statements by other Federal Reserve officials. This finding is consistent with the power of the Chairman to set and affect the agenda, and with the advantage of more frugal and clear communication. We group emerging markets into those with "robust" fundamentals (ten countries) and those with "fragile" fundamentals (sixteen countries) and, intriguingly, find that stronger countries, on average, were generally more adversely exposed in the short run to tapering news than the countries with weak fundamentals, especially in the depreciation of their currencies. In particular, the exchange rate depreciated in both groups immediately following tapering news from Chairman Bernanke, yet the depreciations of the stronger group were three times as large as the weaker group. Looking at these linkages in detail, we find that higher current account balances, higher foreign exchange rate reserves, and lower external debt are associated with greater exchange rate depreciation following Bernanke tapering announcements. Over the period of a month, however, we find asset price movements to tapering announcements are quite similar for both the fragile and robust groups. Finally, we find that more financially developed emerging markets were also more affected by Bernanke tapering announcements.

A possible interpretation of these findings is that countries with weaker fundamentals and less financial development were less exposed to the inflows triggered by quantitative easing, and exchange rates responded less, in line with the conjecture that being closer to financial autarky provides deeper insulation from financial news. The flip side is that tapering news had less impact on exchange rates in these countries. Yet, these findings are also consistent with a less sanguine interpretation, reflecting financial markets' initial inattention to tail risks, overlooking the vulnerability of the weaker emerging markets to the adverse implications of higher future global interest rates. Indeed, in the last quarter of 2013, financial markets refocused 
attention on the fragile emerging markets, with depressed financial asset prices of the "Fragile Five"-Brazil, India, Indonesia, South Africa, and Turkey - a subgroup of the weaker emerging markets 1 Interestingly, however, it appears that differential responses between the fragile and robust group tend to dissipate over time.

The methodology of our paper complements Eichengreen and Gupta (2014), who used data for exchange rates, foreign reserves, and equity prices between April and August 2013 to analyze who was hit and why. They concluded that better fundamentals did not provide insulation. Instead, countries with larger markets experienced more pressure on the exchange rate, foreign reserves, and equity prices. Our focus on the event methodology allows us to trace the immediate impact effect of the coming news on expectation of adjustment, as reflected in the changes of key prices triggered by the news.

The next section presents the data and methodology of the study. Section 3 presents the main results. Section 4 presents extensions and robustness checks of the basic models. Section 5 concludes.

\section{Data and Methodology}

\subsection{Data}

Our objective is to evaluate the transmission of U.S. tapering "news" to financial markets in emerging markets. In undertaking this analysis, we consider announcements associated with support (or actions) of quantitative easing as well as tapering. During the period of time under investigation-November 27, 2012 through October 3, 2013 - there were numerous statements in support of both policies by Chairman Bernanke, Federal Reserve governors, Federal Reserve Bank presidents, and the FOMC statement following meetings, as well as FOMC minutes from past meetings. This allows us to evaluate the symmetry of the effects of the announcements, not only for $\mathrm{QE}$ and tapering but also for different sources of the statements. In

\footnotetext{
${ }^{1}$ The market inattention to tail risks was vividly illustrated by the euro crisis, where the pre-crisis sovereign spreads of Greece, Portugal, and Spain were comparable to that of Germany and other euro-zone core countries (Aizenman, Hutchison, and Jinjarak 2013). See also Aizenman, Binici, and Hutchison (2013) for an overview of other issues in the pricing of risk during the euro crisis.
} 
particular, we focus on six types of announcements from the Federal Reserve: statements by Federal Reserve Chairman Bernanke, either in support of further quantitative easing (QE) or tapering (Tap); release of statements following the FOMC meetings either supporting further QE or Tap; and statements by governors of the Federal Reserve System (other than Bernanke) or by presidents of the Federal Reserve Banks either supporting QE or Tap.

To gather this information, we conducted two sets of news searches on Bloomberg. The first search was for the keywords "QE Federal." Additionally, to focus on the tapering aspect of the QE announcements, another search was performed for the keywords "Federal Reserve Bank of," "QE," and "Fed Taper." A filter was applied to select "News" for both searches. To verify whether the announcement and speech "news" were coded consistently with how they were perceived by the markets in the United States (not emerging markets), we examined articles and other publications from the Factiva database. We utilized the date and topic filtering available in the database to solicit descriptions of the perception as well as the corresponding market reactions of the announcement/speech. We closely examined each of the original Bloomberg coding for announcements to determine whether they matched the perceptions found in the Factiva publications. There were many more announcements/statements/speeches on these topics than were coded. In order to be coded as either supporting further (or continuing) QE or tapering, the announcements needed to be unambiguous.

Table 1 presents some summary statistics on our announcements as well as examples of announcement coding and the division between "tapering" and "quantitative easing." We found three cases (seven cases) where Chairman Bernanke clearly indicated tapering was a favored policy option (further or continuing QE was a favored policy option); five cases where the FOMC statements/minutes clearly favored QE (and none clearly favored tapering); and a rough balance between governors/presidents speaking unambiguously in favor of QE (twenty-two cases) or tapering (twenty-six cases).

We consider three main conduits through which these variables may affect emerging markets: daily changes in national stock markets (log first differences), daily changes in foreign exchange rates (log first differences), and daily changes in CDS spreads (in basis points). If tapering is expected to reduce financial flows to emerging 


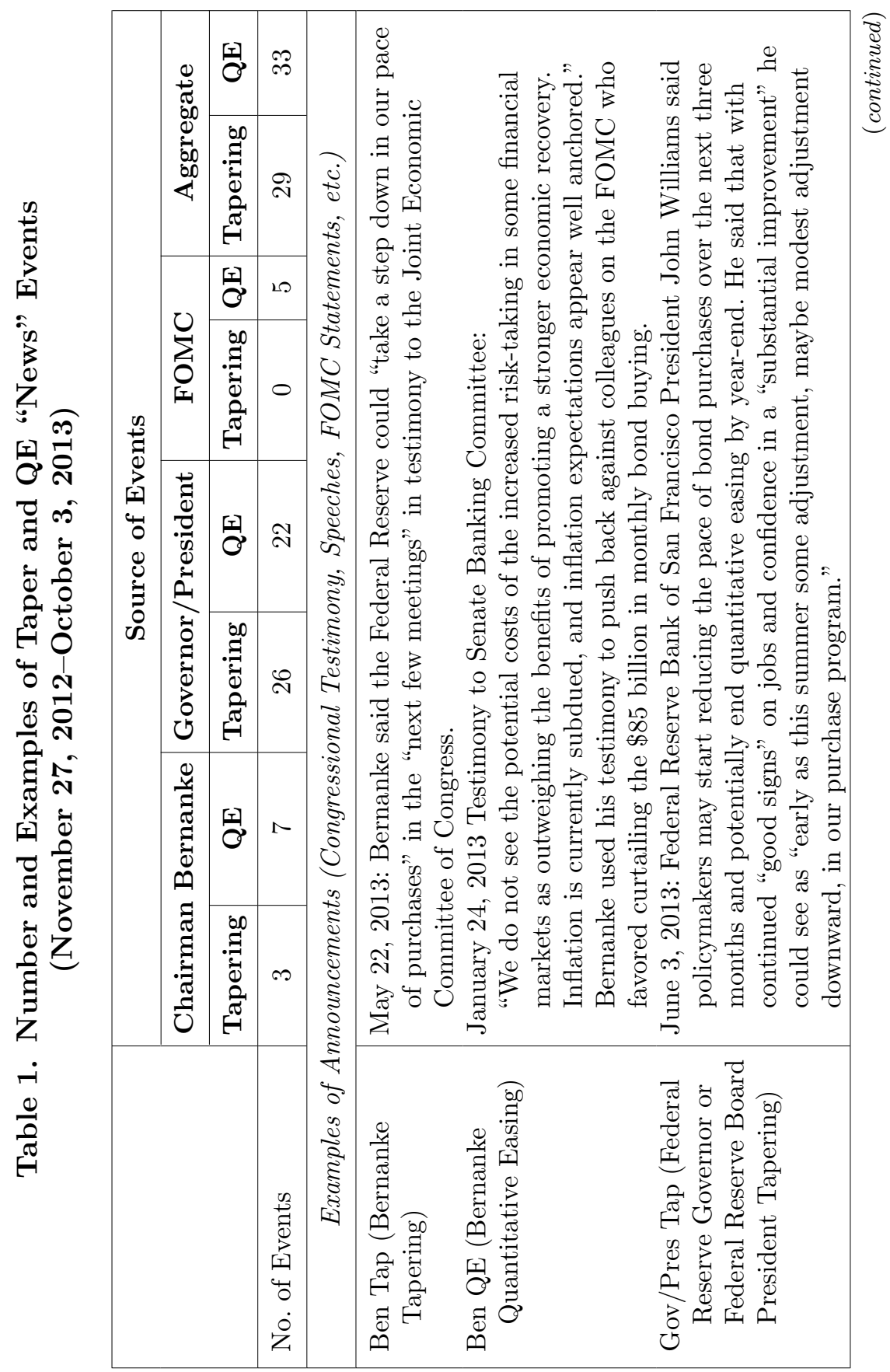




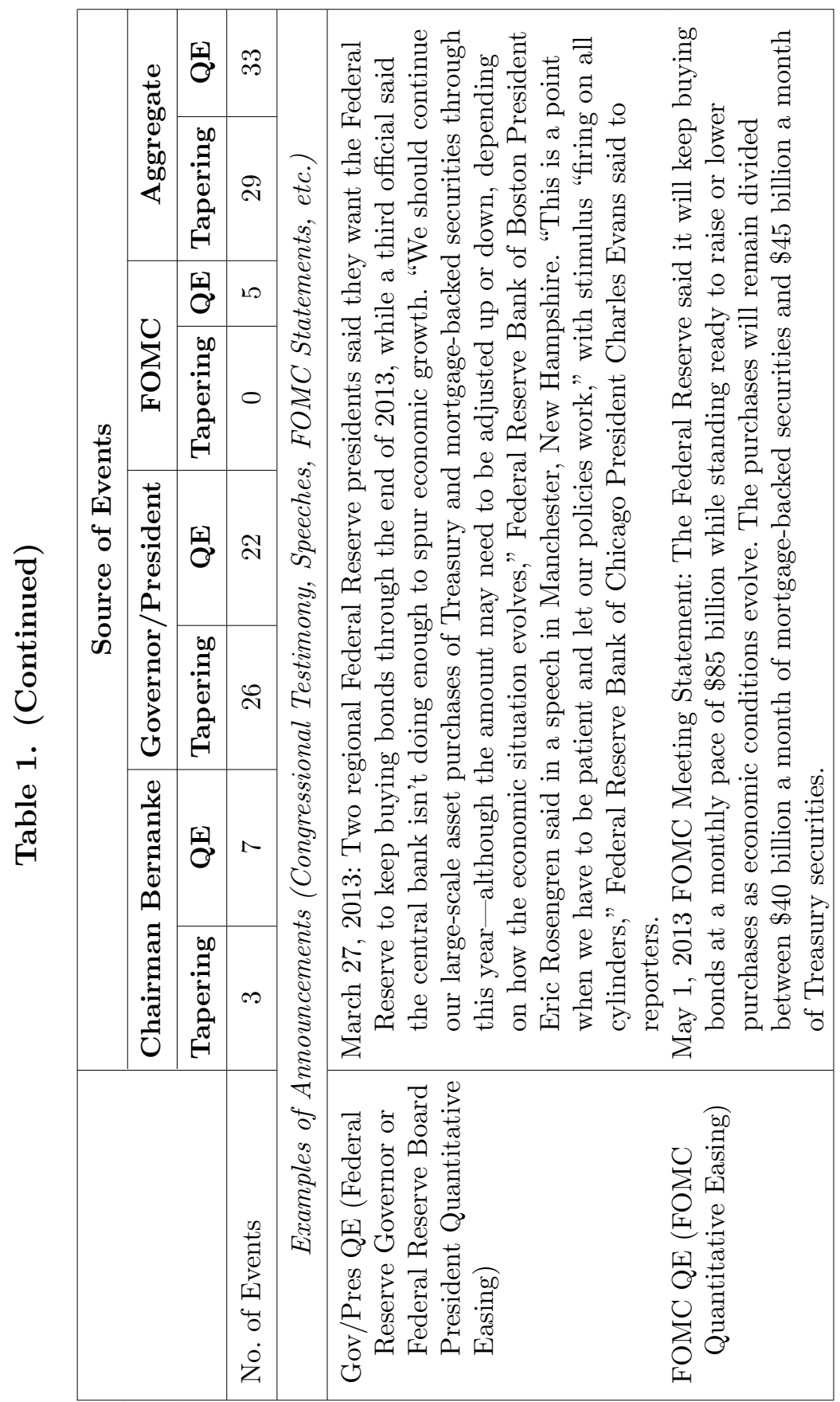


markets, then we would expect national equity markets to fall, exchange rates to depreciate, and (perhaps) CDS spreads to rise. We focus on twenty-six emerging markets, shown in table 2. (The "fragile" and "robust" groups and statistics are explained below.) Emerging markets were required to have stock market and CDS price data for the entire sample period to be included in the sample.

\subsection{Methodology}

We employ panel fixed-effect estimation techniques to estimate the impact of U.S. Federal Reserve announcements on financial market prices in emerging markets. We estimate a panel data model of the following form:

$$
\begin{aligned}
& \Delta P_{i t}=\beta_{0}+\beta_{1} \text { Ben Tap } \text { Tap }_{t}+\beta_{2} \text { Ben } Q E_{t}+\beta_{3} \text { GovPres Tap } \\
& +\beta_{4} \text { GovPres } Q E_{t}+\beta_{5} \text { FOMC QE } E_{t}+\mu_{i}+\varepsilon_{i t} \text {, }
\end{aligned}
$$

where $\Delta P_{i t}$ is the log first difference in foreign exchange rates, national equity markets, or the change in CDS spread for country $i$ at time $t$. Ben $\operatorname{Tap}_{t}$ (Ben $Q E_{t}$ ) are statements supporting tapering (further quantitative easing) by Chairman Bernanke at time $t$;

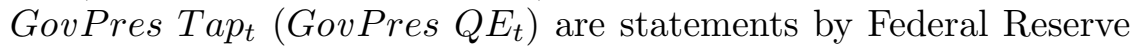
Board governors or Federal Reserve Bank presidents in support of tapering (further quantitative easing); and $F O M C Q E_{t}$ are official statements following FOMC meetings supporting further quantitative easing. (No official FOMC statements supporting tapering were identified during this sample period.)

We find no evidence of dynamic adjustment in asset price movements (log first differences in equity markets and exchange rates, first differences in CDS spreads) and considered all news events emanating from the United States as strictly exogenous for emerging markets. We therefore estimate the model as a static panel with country fixed effects. We report robust standard errors clustered with countries, and do not find any evidence of serial correlation in residuals. To take time differences between U.S. and Asian markets countries into account, all Federal Reserve announcements (independent variables) are lagged one day for South Korea, Malaysia, Philippines, Thailand, China, Indonesia, India, and Pakistan. For the rest of the countries, news events are entered in the model contemporaneously. 
Table 2. Emerging-Market Sample

\begin{tabular}{|c|c|c|c|}
\hline Country & $\begin{array}{c}\mathrm{CAB} / \mathrm{GDP} \\
(\%)\end{array}$ & $\begin{array}{l}\text { Reserves/ } \\
\text { GDP (\%) }\end{array}$ & $\begin{array}{c}\text { External } \\
\text { Debt/GDP (\%) }\end{array}$ \\
\hline \multicolumn{4}{|c|}{ Robust Group } \\
\hline $\begin{array}{l}\text { Peru } \\
\text { Israel } \\
\text { Korea } \\
\text { Malaysia } \\
\text { Philippines } \\
\text { Thailand } \\
\text { Bulgaria } \\
\text { Russia } \\
\text { China } \\
\text { Hungary }\end{array}$ & $\begin{array}{r}-4.89 \\
2.33 \\
4.61 \\
3.49 \\
2.51 \\
0.11 \\
1.15 \\
2.89 \\
2.50 \\
2.22\end{array}$ & $\begin{array}{l}31.11 \\
28.68 \\
26.86 \\
43.11 \\
27.04 \\
41.09 \\
32.66 \\
22.44 \\
39.32 \\
34.22\end{array}$ & $\begin{array}{r}25.72 \\
37.00 \\
37.74 \\
32.87 \\
30.34 \\
37.04 \\
72.56 \\
31.56 \\
8.99 \\
136.53\end{array}$ \\
\hline \multicolumn{4}{|c|}{ Fragile Group } \\
\hline $\begin{array}{l}\text { Turkey } \\
\text { South Africa } \\
\text { Argentina } \\
\text { Brazil } \\
\text { Chile } \\
\text { Colombia } \\
\text { Mexico } \\
\text { India } \\
\text { Indonesia } \\
\text { Pakistan } \\
\text { Ukraine } \\
\text { Czech R. } \\
\text { Latvia } \\
\text { Lithuania } \\
\text { Poland } \\
\text { Romania }\end{array}$ & $\begin{array}{l}-7.38 \\
-6.07 \\
-0.75 \\
-3.38 \\
-4.58 \\
-3.22 \\
-1.34 \\
-4.41 \\
-3.41 \\
-0.97 \\
-7.29 \\
-1.76 \\
-1.14 \\
-0.26 \\
-3.03 \\
-1.96\end{array}$ & $\begin{array}{r}12.85 \\
11.82 \\
7.13 \\
16.75 \\
14.55 \\
10.82 \\
12.37 \\
15.02 \\
12.55 \\
3.10 \\
12.37 \\
21.75 \\
23.82 \\
15.15 \\
20.03 \\
22.95\end{array}$ & $\begin{array}{r}43.30 \\
34.40 \\
24.25 \\
19.74 \\
42.61 \\
22.18 \\
29.90 \\
20.85 \\
25.86 \\
24.49 \\
78.49 \\
52.33 \\
140.82 \\
79.00 \\
75.37 \\
77.38\end{array}$ \\
\hline \multicolumn{4}{|c|}{$\begin{array}{l}\text { Notes: Current account balance (in percent of GDP) and international reserves (in } \\
\text { percent of GDP) data is taken from the International Monetary Fund's World Eco- } \\
\text { nomic Outlook Database, and external debt (in percent of GDP) is from the Central } \\
\text { Intelligence Agency's World Factbook. A country is grouped under "robust" or "frag- } \\
\text { ile" based on whether it has current account surplus, high reserves, and low external } \\
\text { debt. Thus, if at least two of three (or three of three) of the above criteria holds, } \\
\text { then a country is in the "robust group"; otherwise, it is in the "fragile group." Low } \\
\text { international reserve level is defined as a reserves/GDP ratio below } 20 \text { percent, and } \\
\text { low external debt is defined as an external debt/GDP ratio less than } 34 \text { percent. } \\
\text { Both cut-off points are the median values of their respective samples. }\end{array}$} \\
\hline
\end{tabular}


Recognizing the substantial heterogeneity among the twenty-six emerging markets, we grouped the emerging markets according to three fragility/strength criteria: current account deficits or surpluses; low or high international reserves; and high or low external debts 2 We estimated the effects of "news" on the full sample as well as the two subgroups ("robust" and "fragile"). We also grouped countries by their level of financial development ("low" or "high"). As discussed in the introduction, we anticipate different reactions to news depending on the state of the emerging-market economy.

\section{Results}

\subsection{Full-Sample Results}

Table 3 reports the impact of the tapering and QE news on the stock market indices, exchange rates, and sovereign spreads for the full sample of twenty-six emerging markets from November 27, 2012 to October 3, 2013. These regression results summarize the change of market prices in the twenty-four-hour window following the news.

Tapering. Bernanke's tapering news was associated with significant drops in stock market indices and exchange rate depreciations, but had no significant impact on sovereign spreads. This may reflect the expectation of reduced capital inflows and carry-trade activity to emerging markets, with less investment in equity markets. Not surprisingly, tapering news doesn't seem to affect CDS spreads on sovereign debt. By contrast, numerous and frequently quite vigorous statements in support of tapering by Federal Reserve Bank presidents had little discernible effect on emerging-market financial prices - equities, exchange rates, or CDS spreads - during our sample period. (No tapering news was attributable to Federal Reserve governors during this period, only Federal Reserve Bank presidents.) This may be because one of the Federal Reserve Bank presidents-Fisher of the Federal Reserve Bank of Dallas - made many public statements advocating tapering (nine of our twenty-six events) that may have been discounted by financial markets due to their frequency and

\footnotetext{
${ }^{2}$ Low international reserve level is defined as a reserves/GDP ratio below 20 percent, and low external debt is defined as an external debt/GDP ratio less than 34 percent. Both cut-off points are the median values of their respective samples.
} 


\section{Table 3. Full Sample-Asset Market Reaction to Federal Reserve Announcements}

\begin{tabular}{|c|c|c|c|}
\hline & $\begin{array}{c}\text { Stock Market } \\
\text { (1) }\end{array}$ & $\begin{array}{c}\text { Exchange Rate } \\
(2)\end{array}$ & $\begin{array}{c}\text { CDS Spreads } \\
(3)\end{array}$ \\
\hline Ben Tap & $\begin{array}{r}-0.328^{*} \\
(0.164)\end{array}$ & $\begin{array}{l}0.219^{* * *} \\
(0.064)\end{array}$ & $\begin{array}{r}-0.550 \\
(4.075)\end{array}$ \\
\hline Ben QE & $\begin{array}{c}0.128 \\
(0.128)\end{array}$ & $\begin{array}{c}-0.141^{* * *} \\
(0.037)\end{array}$ & $\begin{array}{r}-1.419 \\
(1.122)\end{array}$ \\
\hline Gov/Pres Tap & $\begin{array}{c}0.035 \\
(0.043)\end{array}$ & $\begin{array}{c}-0.010 \\
(0.012)\end{array}$ & $\begin{array}{c}0.564 \\
(0.717)\end{array}$ \\
\hline Gov/Pres QE & $\begin{array}{c}-0.176^{* * *} \\
(0.052)\end{array}$ & $\begin{array}{c}-0.097^{* * *} \\
(0.018)\end{array}$ & $\begin{array}{r}-3.689 \\
(4.417)\end{array}$ \\
\hline FOMC QE & $\begin{array}{l}0.164^{* *} \\
(0.079)\end{array}$ & $\begin{array}{l}-0.252^{* * *} \\
(0.045)\end{array}$ & $\begin{array}{r}-3.535^{*} \\
(1.936)\end{array}$ \\
\hline Constant & $\begin{array}{l}0.047^{* * *} \\
(0.009)\end{array}$ & $\begin{array}{l}0.033^{* * *} \\
(0.004)\end{array}$ & $\begin{array}{c}0.421 \\
(0.497)\end{array}$ \\
\hline Observations & 5,590 & 5,375 & 5,156 \\
\hline R-squared & 0.004 & 0.012 & 0.001 \\
\hline No. of Countries & 26 & 25 & 24 \\
\hline \multicolumn{4}{|c|}{$\begin{array}{l}\text { Notes: The table presents panel fixed-effect estimation results with robust standard } \\
\text { errors in parentheses. } * * *, * * \text {, and } * \text { denote } \mathrm{p}<0.01, \mathrm{p}<0.05 \text {, and } \mathrm{p}<0.1 \text {, respec- } \\
\text { tively. Independent variables are log first difference of stock market index, foreign } \\
\text { exchange rate, and change in CDS spreads in specification } 1,2 \text {, and } 3 \text {, respectively. } \\
\text { Exchange rate estimation excludes China; CDS spread estimation excludes China } \\
\text { and Pakistan. }\end{array}$} \\
\hline
\end{tabular}

predictability of the message. (The other most vocal advocate for tapering was Philadelphia Federal Reserve Bank President Plosser, with five news events during the sample period.) No explicit and unambiguous news in support of tapering in FOMC announcements was coded during this period.

Quantitative Easing. Bernanke's QE news, symmetrically, was associated with strong exchange rate appreciation in table 3 . Exchange rates also significantly appreciated in response to $\mathrm{QE}$ news contained in FOMC statements and in announcements by governors/presidents, where the FOMC had the largest impact and governors/presidents had the least impact. The support for QE was broader than tapering, including governors (Vice Chair Yellen and Governors Duke and Stein) and many presidents. President 
Rosengren (Boston) and President Bullard (St. Louis) spoke the most frequently (four times each) in support of continuing QE. In addition, consistent with the very strong impact of FOMC QE news exchange rate appreciation, these statements also had a large impact on pushing up stock market prices.

\subsection{Differential Effects of Tapering}

As discussed above, we expect tapering news to have different effects depending on the strength of a country's international "fundamentals." Full-sample results, in turn, could mask differential effects due to group heterogeneity associated with disparate fundamentals. To address this issue, tables 4-6 report the impact of the tapering and QE news on market prices, allowing comparison between countries having current account deficits/surpluses (table 4), low/high international reserves (table 5), and high/low external debts (table 6). (Table 2 presents the external positions of countries and the grouping between "robust" and "fragile" countries.) We also group countries in terms of these fundamentals, robust and fragile, where the robust group are countries that meet at least two "strong" criteria (current account surplus, higher reserves, and low debt), and the fragile group meet at least two "weak" criteria (current account deficits, low reserves, and high debt). The countries in each group are shown in table 2, and table 7 reports the regression results for these two groups.

This comparison reveals asymmetric and divergent patterns, depending on whether the news is emanating from Bernanke's statements, as opposed to governors/presidents and the FOMC, and between the groups with robustness or fragile fundamentals. In particular, Bernanke's tapering news had much larger exchange rate depreciation effects on countries with (i) current account surpluses as opposed to deficits (four times larger, table 4), (ii) high international reserves contrasted with low reserves (three times larger, table 5), and (iii) low external debt rather than high debt (about half as much larger, table 6) 3 The analysis of the two groups - fragile or robust,

\footnotetext{
${ }^{3}$ The differences between the groups are statistically significant in the cases of exchange rates (chi-square of 4.56 and probability of 0.033 ) and international reserves.
} 


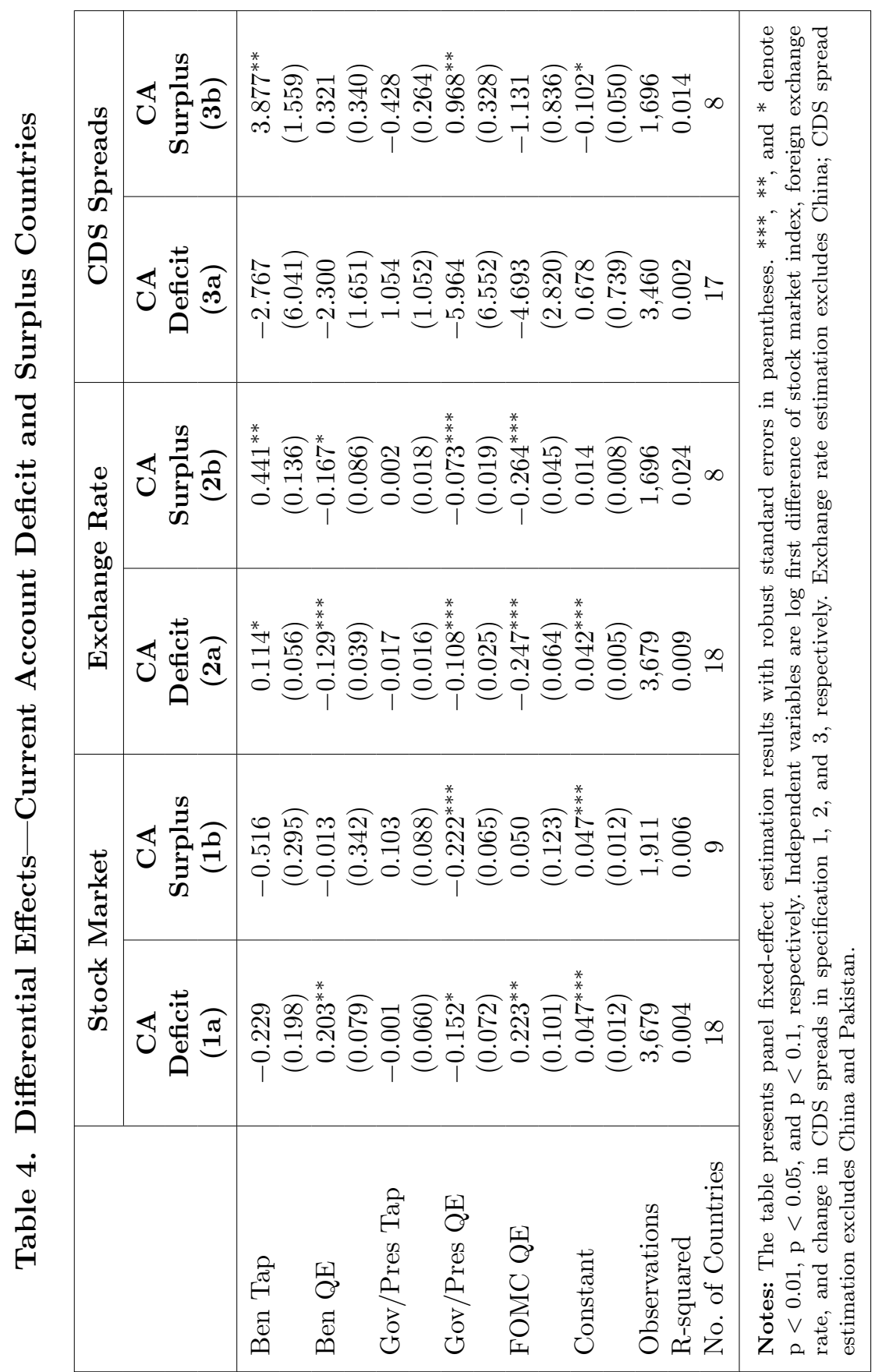




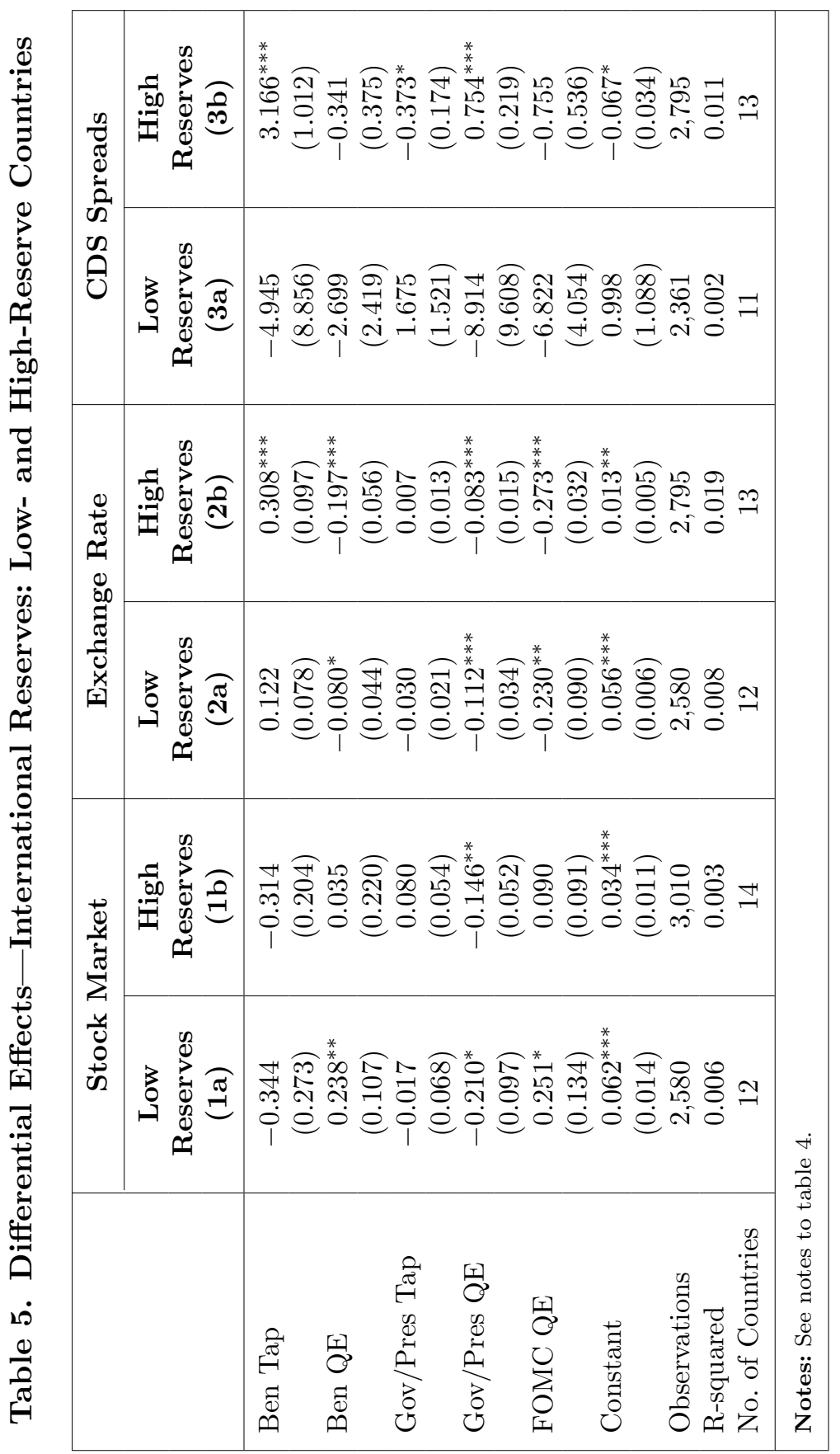




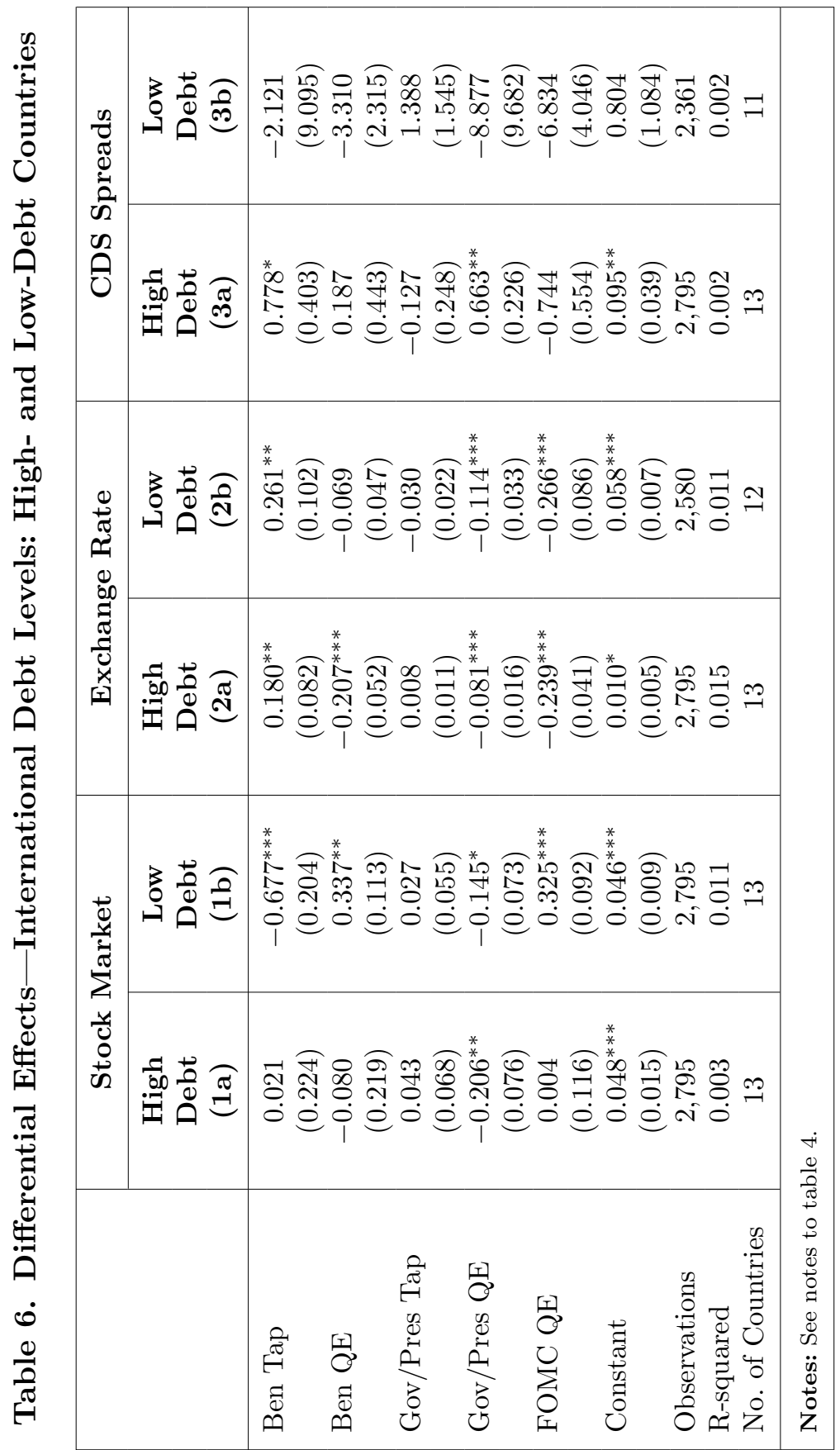




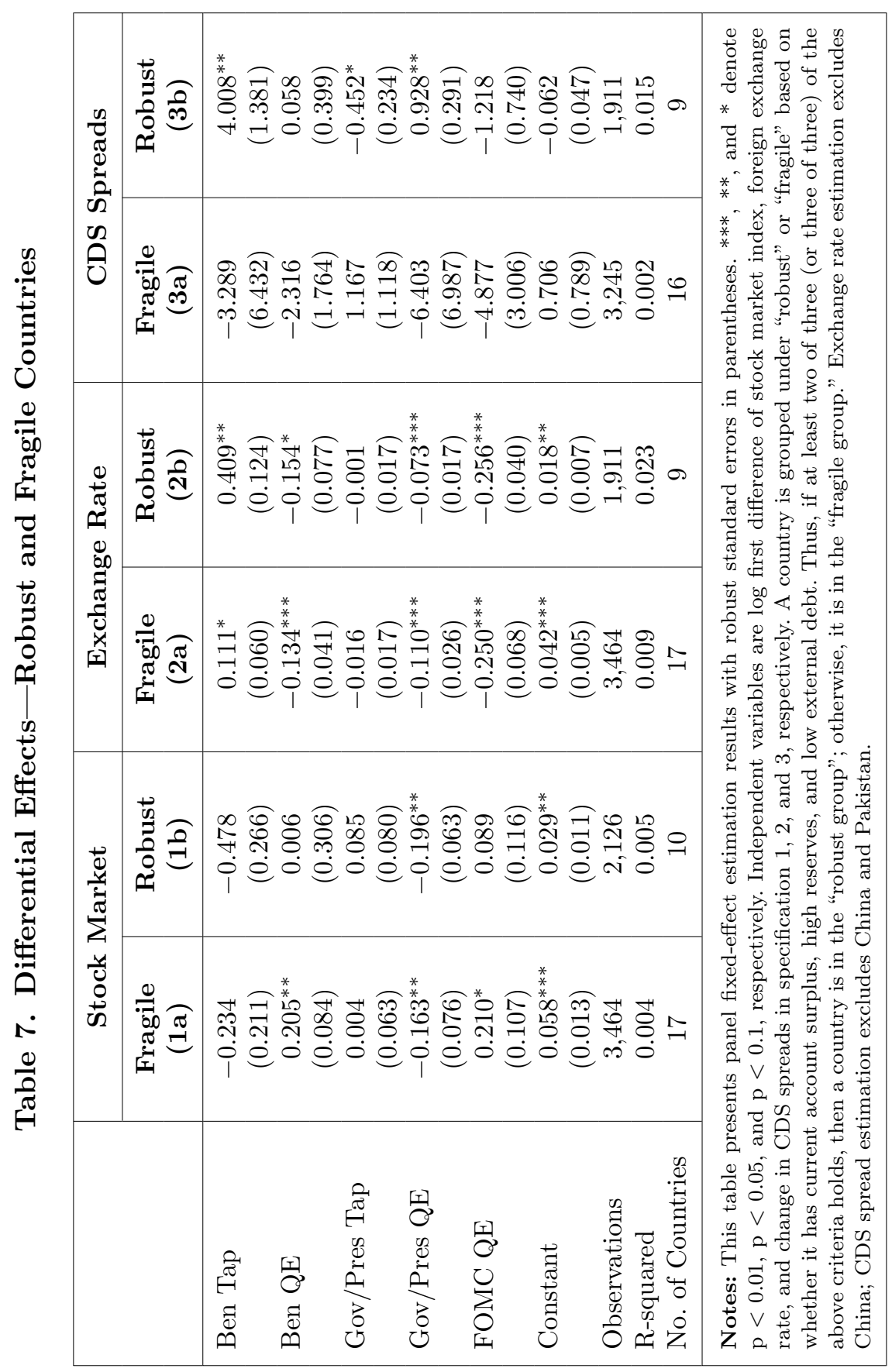


shown in table 7 -also indicates that exchange rate depreciation is statistically significant in both cases at the time of Bernanke's tapering announcements but more than three times larger in the robust group (0.409) compared with the fragile group (0.111) 4

By contrast, tapering announcements by Federal Reserve governors or presidents had little or no discernible impact on exchange rates in emerging markets, regardless of whether they were classified as robust/weak in fundamentals, had current account surpluses or deficits, had high/low international reserves, or had low/high external debt. This is consistent with the full-sample results.

Bernanke's tapering news increased CDS spreads very substantially for countries with robust fundamentals (4.0 points; table 7 ), and especially for those countries with current account surpluses (3.8 points; table 4 ) and high international reserves (3.2 points; table 5), while having little or no effect on fragile countries (except for increasing spreads marginally, 0.77 points, for those with high external debt positions). And, similar to the full-sample results, tapering announcements by Federal Reserve governors/presidents had little effect on CDS spreads, lowering them overall by only -0.45 (table 7; significant at the 10 percent level), apparently attributable to the small decline in CDS in the high-reserves group $(-0.37$; table 5).

Bernanke's tapering news lowered equity market values in emerging markets for the full sample ( -3.28 percent; table 3$)$ and in the countries with low external debt positions (table 6). And, similar to the full-sample results, group results based on fundamentals indicated that tapering announcements from governors/presidents did not have any significant impact on stock markets.

Intriguingly, tables 4-7 imply that Bernanke's tapering news depreciated exchange rates most in countries typically associated with strong international positions - countries running current account surpluses, having high reserves, and having low debt-and our aggregate of robust countries. A possible interpretation is that fragile economies were less exposed to financial flows in search of higher yields during the earlier QE years; thereby they were expected to be less exposed to the immediate impact of the tapering news.

\footnotetext{
${ }^{4}$ This difference is statistically significant, with a chi-square of 4.31 (probability 0.038$)$.
} 


\subsection{Differential Effects of Quantitative Easing}

The effects of QE news also showed substantial variation depending on who made the statement and the international position of the country. Bernanke's QE news was associated with strong exchange rate appreciation in the full sample $(-0.14$; table 3$)$ as well as in both fragile and robust groups (table 7 ), where the impact effects were virtually identical ( -0.13 and -0.15 , respectively). Appreciation was an even more dominating characteristic of countries with strong current account positions, high international reserves, and high international debt 5

Significant exchange rate appreciations were also associated with FOMC QE statements in the full sample, in both fragile and weak groups (table 7), and in all of the subsamples (table 4). Interestingly, no asymmetric effects were found between those with weak or strong fundamentals - the coefficients on the exchange rate response to FOMC QE support news were virtually identical (and significant) across subgroups.

Differential effects emerge again in stock market and CDS responses to QE. Bernanke's and the FOMC's QE news were associated with higher stock prices of the fragile group but did not affect the stock prices of the strong group. By contrast, QE news from governors/presidents was associated with lower stock market indices for both fragile and robust groups (table 7), and coefficient estimates are similar in magnitudes regardless of international fundamental positions. In terms of CDS spreads, QE news from Federal Reserve governors/presidents had no discernible effect in the full sample but appears to raise spreads for the robust group of countries (table 7). This result stems from the rise in CDS spreads in countries with high international reserve positions. However, somewhat at odds with the other results, spreads climbed in those countries with relatively high external debt positions. The differential impacts of the news source reflect the much higher frequency of news from governors/presidents (twenty-six tapering, twenty-two QE) in comparison with news from Bernanke (three tapering and seven QE) and FOMC QE news (five).

\footnotetext{
${ }^{5}$ The difference between depreciation in countries with high and low international debt positions is statistically significant with a chi-square value of 3.25 (probability 0.072).
} 
On balance, the market was focused and reacted more to the scarcer and more coherent news from Bernanke and the FOMC than to the frequent and diffused news from governors/presidents. Governors'/presidents' news reflected the inner debate among heterogeneous and non-coordinated views of the Federal Reserve's senior officials, whereas Bernanke's and FOMC QE news were viewed as much clearer signals regarding the stance of the Federal Reserve's policies. These interpretations are also supported by the results reported for the full sample (table 3).

\subsection{Robust and Fragile Fundamentals and Tapering Dynamics}

Emerging-market countries with robust (fragile) fundamentalsthose with current account surpluses (deficits), high (low) international reserves, and low (high) external debt - were most (less) affected by tapering announcements, particularly with respect to exchange rates. Robust (fragile) economies seemed to have been more (less) exposed to financial flows in search of higher yields during the earlier QE years, and also more (less) exposed when tapering started, i.e., markets may have expected capital flow reversals to occur mainly in countries that had experienced the largest inflows initially. However, this may simply be the impact effect. Fragile economies could have experienced tapering effects with some delay.

This interpretation is consistent with figures 1-6. Figures 1, 2, and 3 show the impact of Bernanke's tapering announcements on stock prices, exchange rates, and CDS spreads, respectively, for the fragile and strong groups. Though we find the impact effects of Bernanke's tapering news depreciated exchange rates most in the robust group, the fragile group experienced more depreciation after several months (figure 1). And while Bernanke's tapering news caused CDS spreads to rise substantially more in the robust group, CDS spreads eventually climbed more in the fragile group (figure 3 ). Stock prices did not show significant differential impact effects across the fragile and robust groups, but over time it appears that the robust group has performed less well.

More formally, table 8 considers the differential impact of announcements on cumulative asset price changes over twenty-one business days (approximately one month). The negative cumulative 


\section{Figure 1. Foreign Exchange Rate and Tapering "Events"}

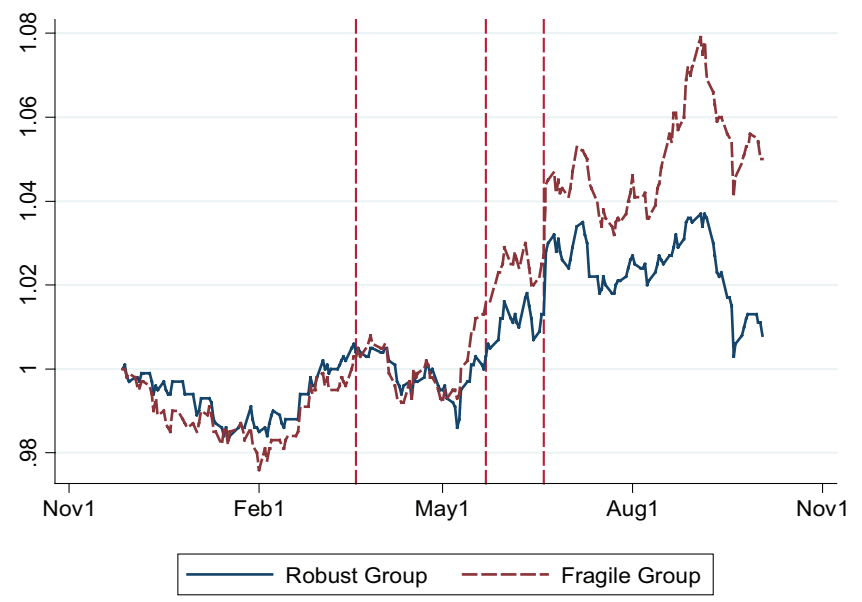

Notes: Vertical dashed lines indicate Bernanke's tapering announcement dates (March 20, 2013; May 22, 2013; June 19, 2013) as described in the data section. For each country, the nominal exchange rate (national currency per U.S. dollar) index is constructed by setting the value equal to " 1 " at the beginning of our sample, November 27, 2012. The (unweighted) average for the "robust group" (Peru, Israel, South Korea, Malaysia, Philippines, Thailand, Bulgaria, Russia, and Hungary) and the "fragile group" (Turkey, South Africa, Argentina, Brazil, Chile, Colombia, Mexico, India, Indonesia, Pakistan, Ukraine, Czech Republic, Latvia, Lithuania, Poland, and Romania) is taken on each day over the sample.

effect of Bernanke's tapering news on fragile economies is somewhat larger on equity prices than in robust economies. The cumulative impact on exchange rate depreciation in fragile and robust economies following Bernanke's tapering announcements is very similar. By contrast, fragile countries experienced twice the average cumulative increase in CDS spreads (45 basis points) as did robust countries (18 basis points) in response to Bernanke's tapering announcements. The cumulative impacts of tapering announcements by the Federal Reserve governors/presidents is more mixed - relatively small declines in equity markets for the fragile group, greater exchange rate depreciation for the fragile group, and a much larger (though not statistically significant) rise in CDS spreads for the fragile group. 


\section{Figure 2. Stock Market Index and Tapering "Events"}

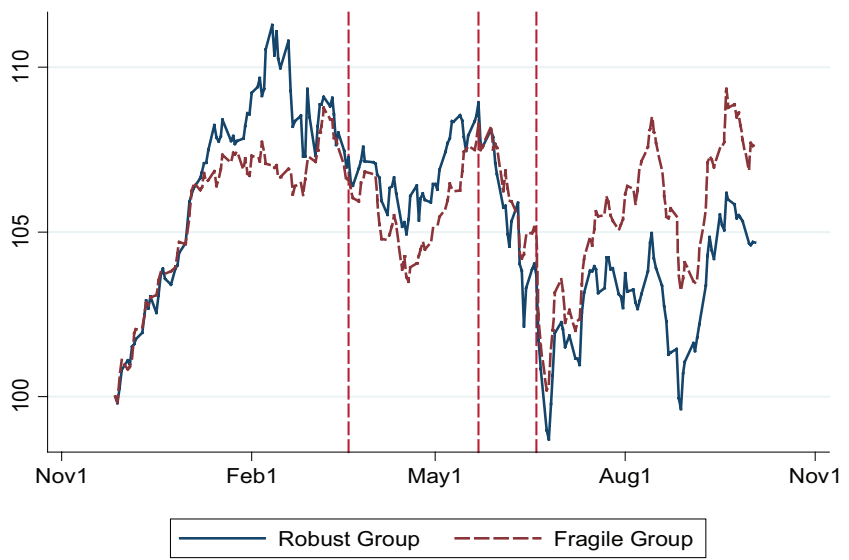

Notes: Vertical dashed lines indicate Bernanke's tapering announcement dates (March 20, 2013; May 22, 2013; June 19, 2013) as described in the data section. For each country, the stock market index is constructed by setting the value equal to "100" at the beginning of our sample, November 27, 2012. The (unweighted) average for the "robust group" (Peru, Israel, South Korea, Malaysia, Philippines, Thailand, Bulgaria, Russia, and Hungary) and the "fragile group" (Turkey, South Africa, Argentina, Brazil, Chile, Colombia, Mexico, India, Indonesia, Pakistan, Ukraine, Czech Republic, Latvia, Lithuania, Poland, and Romania) is taken on each day over the sample.

Overlapping events is a major drawback when measuring longerduration effects using our methodology. To address this issue, we estimated the effects of Bernanke's tapering news alone on cumulative asset price changes for non-overlapping announcements. Nonoverlapping events in this instance led to a nineteen-day post-event window for the asset price changes and are presented in table 9 . The results are virtually identical to the results presented in the previous table.

Figures 4, 5, and 6 report the stock market indices, exchange rates, and sovereign spreads of Brazil and Turkey (relatively fragile countries) and Hungary (a relatively robust country), from November 27, 2012 to October 3, 2013. Again, toward the end of the sample period, the fragile countries were not insulated from the tapering news. Indeed, over time the fragile countries were hit harder than the stronger countries. 


\section{Figure 3. CDS Spreads and Tapering "Events"}

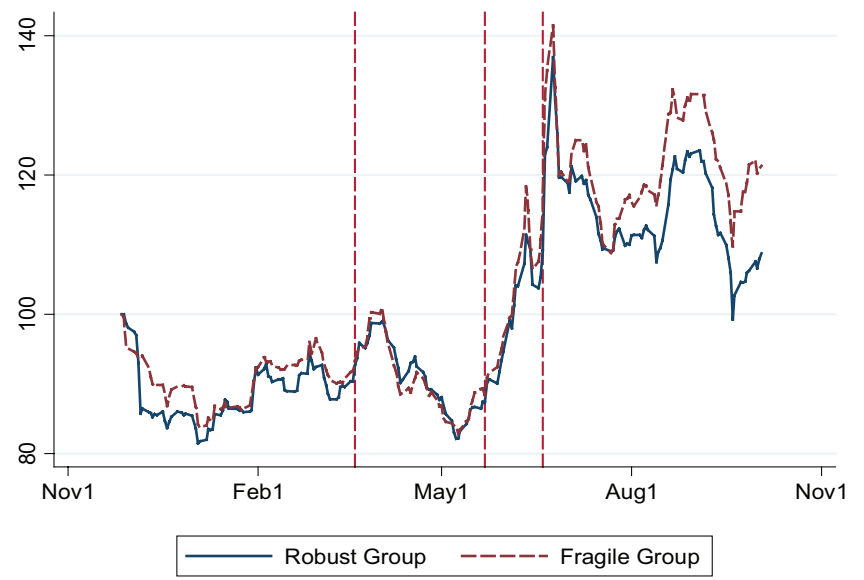

Notes: Vertical dashed lines indicate Bernanke's tapering announcement dates (March 20, 2013; May 22, 2013; June 19, 2013) as described in the data section. For each country, the CDS spread index is constructed by setting the value equal to "100" at the beginning of our sample, November 27, 2012. The (unweighted) average for the "robust group" (Peru, Israel, South Korea, Malaysia, Philippines, Thailand, Bulgaria, Russia, and Hungary) and the "fragile group" (Turkey, South Africa, Argentina, Brazil, Chile, Colombia, Mexico, India, Indonesia, Pakistan, Ukraine, Czech Republic, Latvia, Lithuania, Poland, and Romania) is taken on each day over the sample.

The impact of the tapering news focused first on the strong countries, probably in anticipation of large short-run outflows of past hot money inflows. Market attention shifted over time to the possibility that fragile countries would find it harder to adjust to the higher U.S. interest rates induced by future tapering, leading to large adjustments in the last quarter of 2013. Arguably, the initial large effect of the tapering news, affecting mostly the strong countries, may also reflect financial markets' initial inattention to tail risks, overlooking the vulnerability of the weaker emerging markets to the adverse implications of higher future global interest rates. Indeed, in the last quarter of 2013, financial markets refocused attention on the fragile emerging markets and hammered the prices of the "Fragile Five" Brazil, India, Indonesia, South Africa, and Turkey - a subgroup of the weaker emerging markets. 


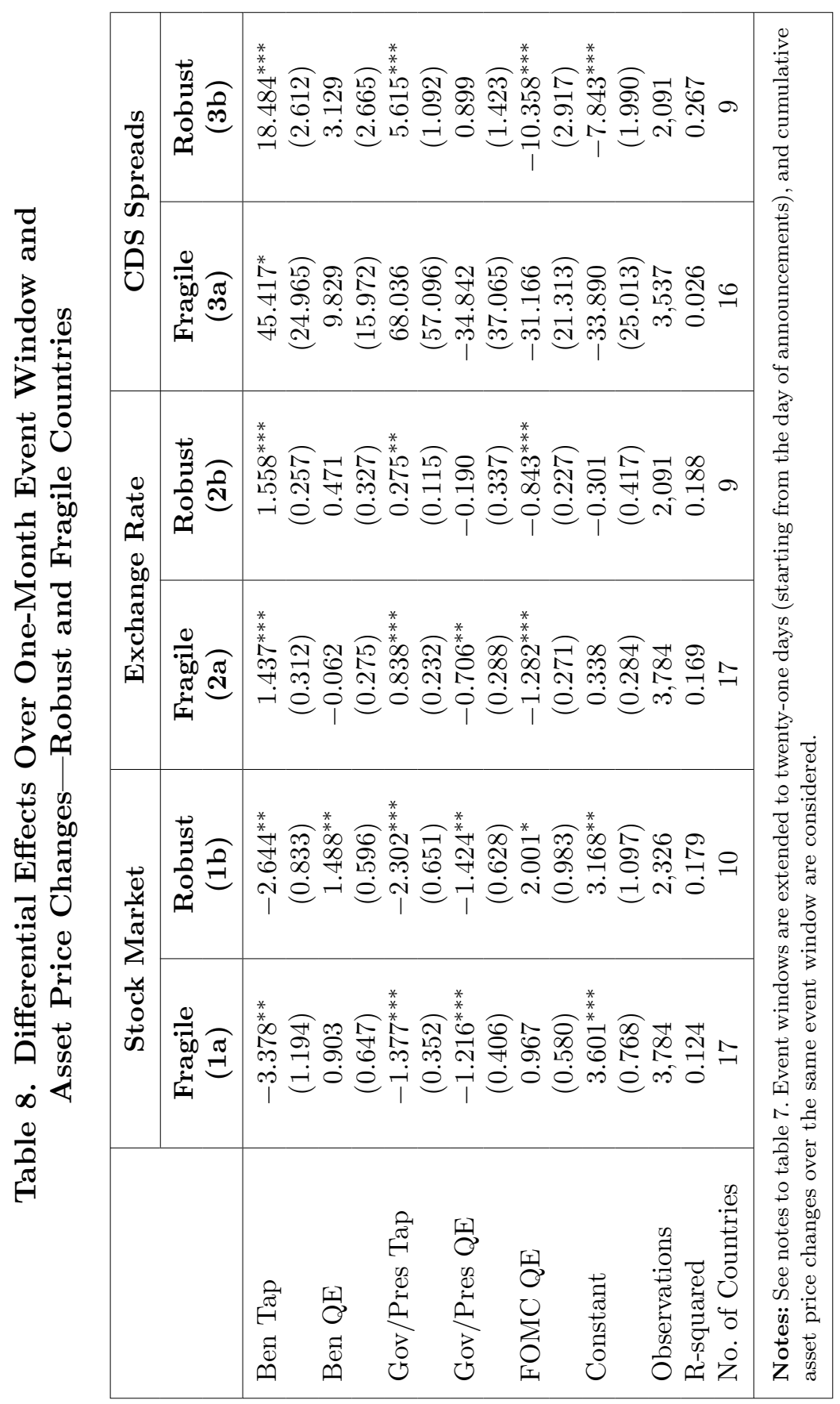




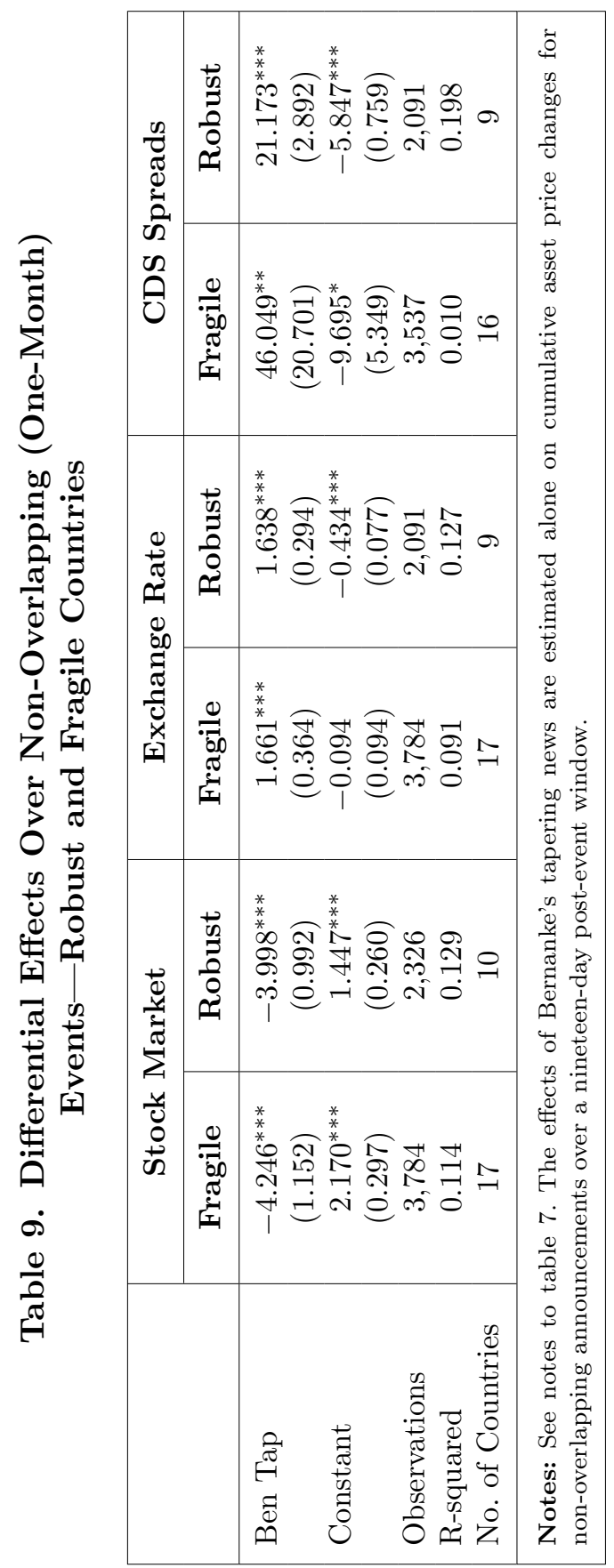




\section{Figure 4. Selected Countries: Stock Market and Tapering "Events"}

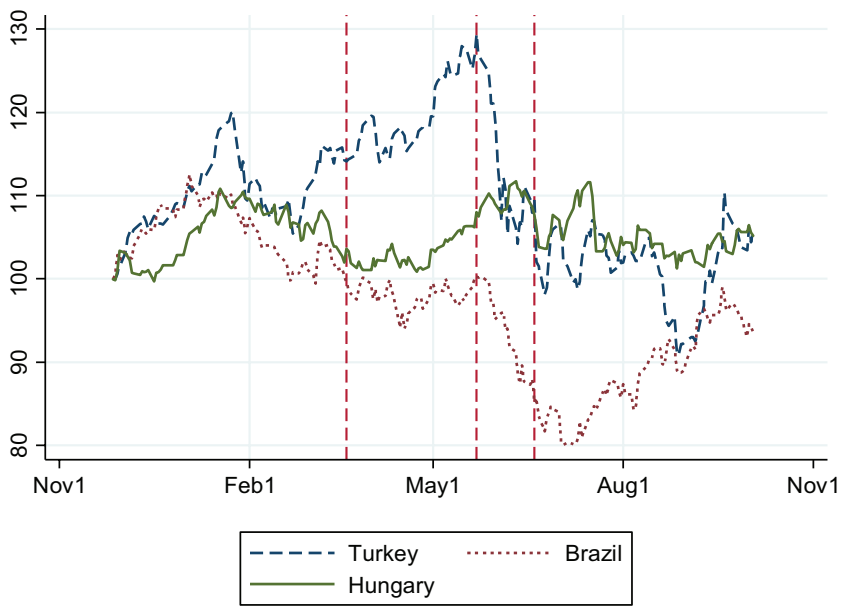

Notes: Vertical dashed lines indicate Bernanke's tapering announcement dates (March 20, 2013; May 22, 2013; June 19, 2013) as described in the data section. For each country, the stock market index is constructed by setting the value equal to "100" at the beginning of our sample, November 27, 2012.

\section{Figure 5. Selected Countries: Foreign Exchange Rate and Tapering "Events"}

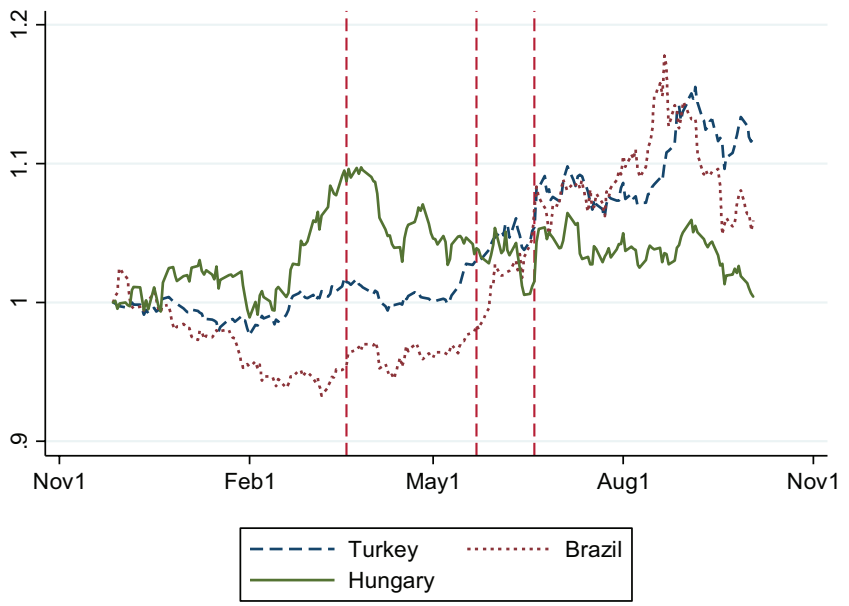

Notes: Vertical dashed lines indicate Bernanke's tapering announcement dates (March 20, 2013; May 22, 2013; June 19, 2013) as described in the data section. For each country, the nominal exchange rate (national currency per U.S. dollar) index is constructed by setting the value equal to " 1 " at the beginning of our sample, November 27, 2012. 


\section{Figure 6. Selected Countries: CDS Spreads and Tapering "Events"}

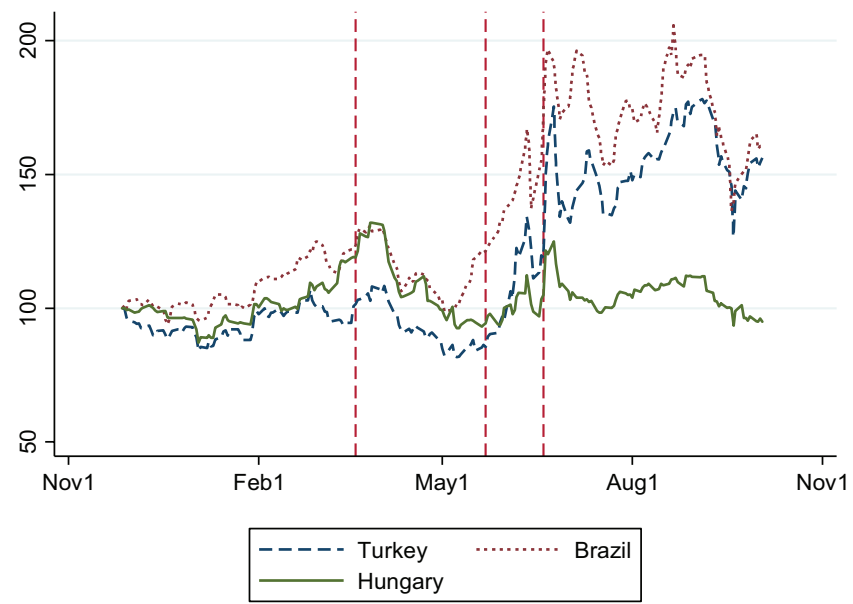

Notes: Vertical dashed lines indicate Bernanke's tapering announcement dates (March 20, 2013; May 22, 2013; June 19, 2013) as described in the data section. For each country, the CDS spread index is constructed by setting the value equal to "100" at the beginning of our sample, November 27, 2012.

\section{Extensions}

\subsection{Fragile and Robust Groupings}

In the previous sections we distinguished between fragile and robust economies using the following criteria: (i) median values for external debt (above the median indicates fragile and below median indicates robust) and international reserves (above median indicates robust and below median indicates fragile), and (ii) current account surpluses (robust) and deficits (fragile). We modify these criteria to be median values for all three fundamentals, i.e., changing our criteria for current accounts from surplus/deficits to above/below the median values in the sample. In table 10 we present results where the classification of a "robust" current account is any value above the median (-1.24) and a "fragile" current account is any value below the median. This gives somewhat different groupings for robust/fragile, with Argentina, Latvia, and Pakistan moving from the fragile to the robust group. Results shown in table 10 are almost identical to 


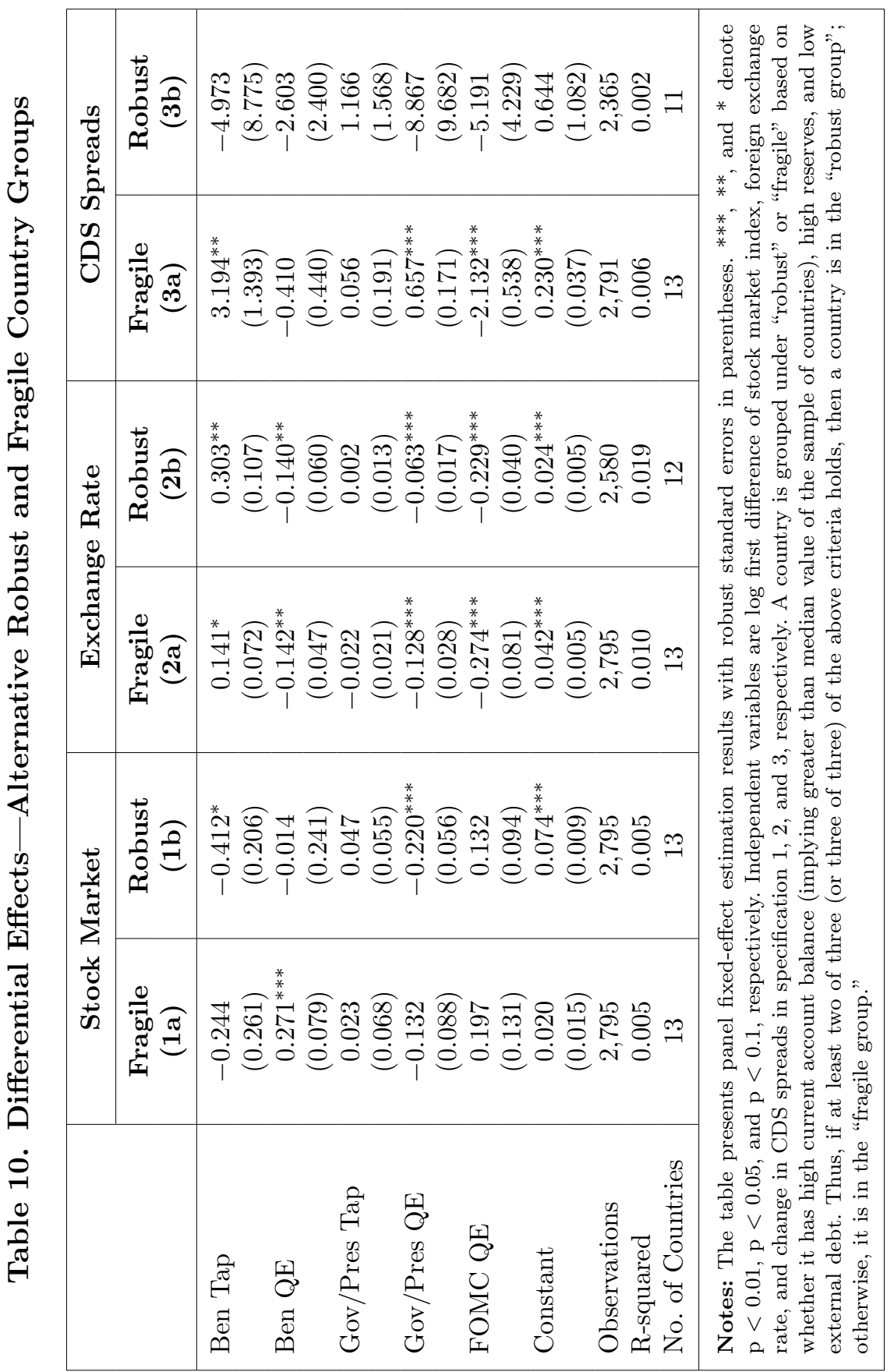


those in table 4, however, and the main results are qualitatively not affected by this change in the robust/fragile groups.

\subsection{Financial Development}

Another issue is whether the degree of financial development is a critical distinguishing characteristic between countries in how they respond to tapering announcements. That is, is this institutional feature important in how tapering and quantitative easing announcements affect asset prices in emerging markets? To address this issue we use the World Economic Forum's Financial Development Index, and use the median value of the sample to divide countries into "high" and "low" degrees of financial development. Table 11 reports the results in an analogous fashion to table 4.

The results indicate that countries with a high degree of financial development had larger declines in equity markets in response to Bernanke's tapering announcements than did those with low degrees of financial development. They also experienced greater exchange rate depreciation and larger increases in CDS spreads than did countries with low levels of financial development. The "tapering response" of more financially developed (less financially developed) emerging economies is broadly similar to those with the robust (fragile) fundamentals, providing an alternative explanation for why these countries were hardest hit by tapering announcements.

\subsection{U.S. Interest Rates}

Another important question is whether tapering and QE announcements are transmitted to emerging-market equity prices, exchange rates, and CDS spreads through U.S. interest rates only, or whether there is an additional transmission channel at work. To address this issue, we included in the baseline regression (table 3) U.S. interest rates of various maturities. In particular, we considered one-month, three-month, six-month, one-year, five-year, ten-year, and twentyyear U.S. Treasury interest rates, each entered separately in the regression equations.

The response of equity prices to Bernanke tapering results was very stable regardless of which U.S. interest rate was included in the regression, with coefficients ranging from -0.321 to -0.428 , all 


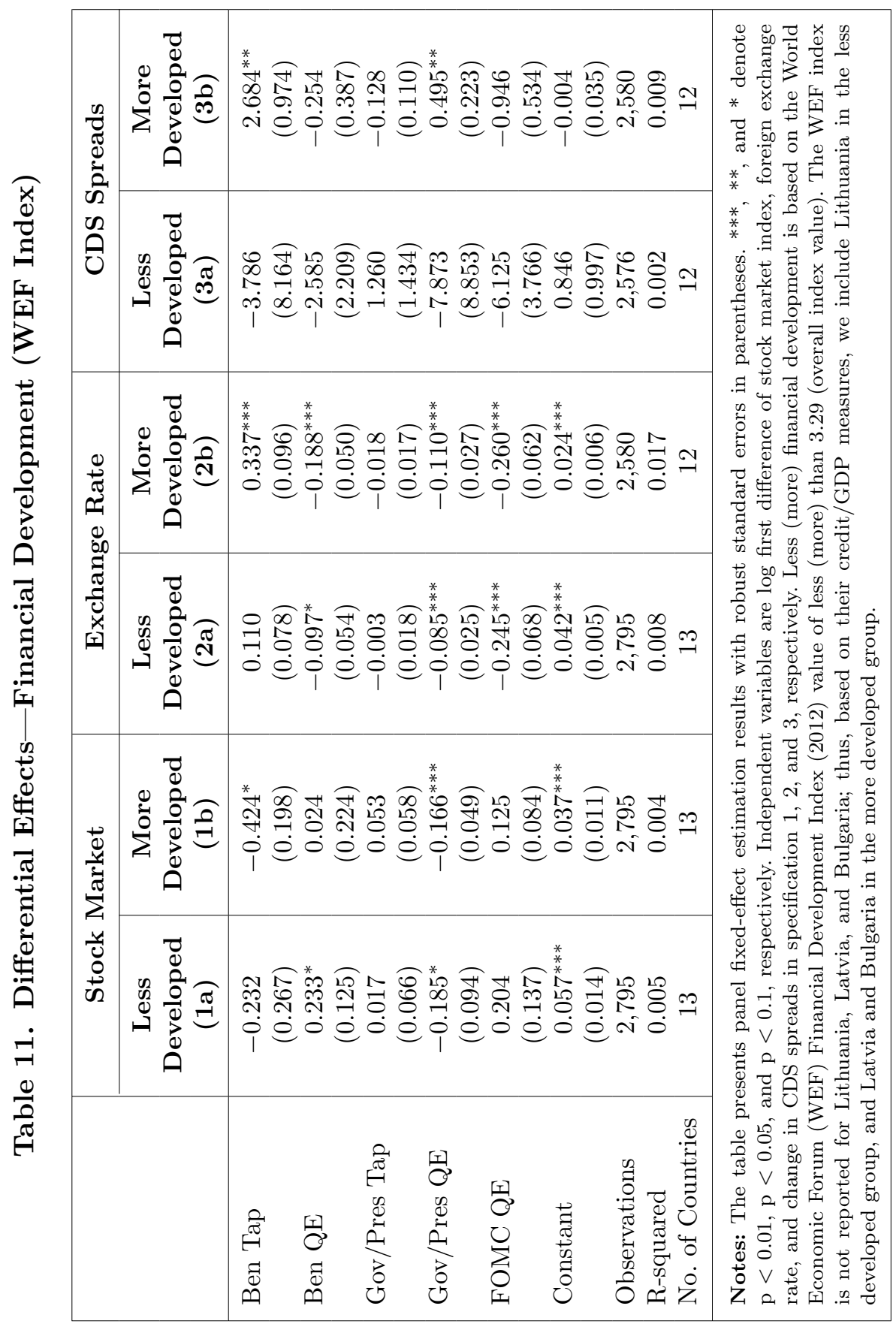


of which were statistically significant (compared with the baseline regression coefficient of -0.327). Similarly, the baseline coefficient on the exchange rate from Bernanke tapering was 0.129, compared with coefficients ranging from 0.123 to 0.225 (six of seven are statistically significant) when U.S. interest rates were included. Bernanke tapering did not have a significant impact on CDS spreads in the baseline regression, and was also not significant in the seven regressions where U.S. interest rates were included. The other results are also very similar to the baseline regressions, indicating that controlling for U.S. interest rates does not change the transmission of tapering (or quantitative easing) "news" announcements on emerging-market asset prices. (Detailed results are not included for brevity but are available from the authors upon request.)

While we focused above on price transmission channels, operating via the exchange rate and asset prices, some transmission may operate through quantities, impacting the emerging markets via capital flows (Caruana 2012). Specifically, tapering information may change the expected future cross-border bank landing (the credit channel) and portfolio flows (market risk taking) 6

\subsection{Interactions with Fundamentals}

An alternative approach to grouping countries with respect to their common fundamentals ("robust" or "fragile") is to interact announcements with the level of the fundamental (e.g., BenTap $\times$ Reserves/GDP). We conduct this analysis for exchange rates and the five types of announcements, reporting the results in table 12 . Table 13 reports the joint significance tests (of the announcement coefficient and the interaction term coefficient). If countries

\footnotetext{
${ }^{6}$ The value of aggregate cross-border bond and equity investment in emergingmarket economies increased from $\$ 3.29$ trillion at the end of 2007 to $\$ 4.46$ trillion at the end of 2012, according to the International Monetary Fund's Coordinated Portfolio Investment Survey. About 85 percent of the increase was in the form of debt, with a much smaller part in equity. Thus, cross-border debt investment has been a significant driver of credit growth in many emerging markets (Mohanty 2014). These developments may have increased the emerging markets' vulnerability. Such borrowing may be highly procyclical, increasing the borrowers' exposure to exchange rate risk - at times of stress, sharp exchange rate depreciations may result in further selling pressure on emerging-market economies.
} 


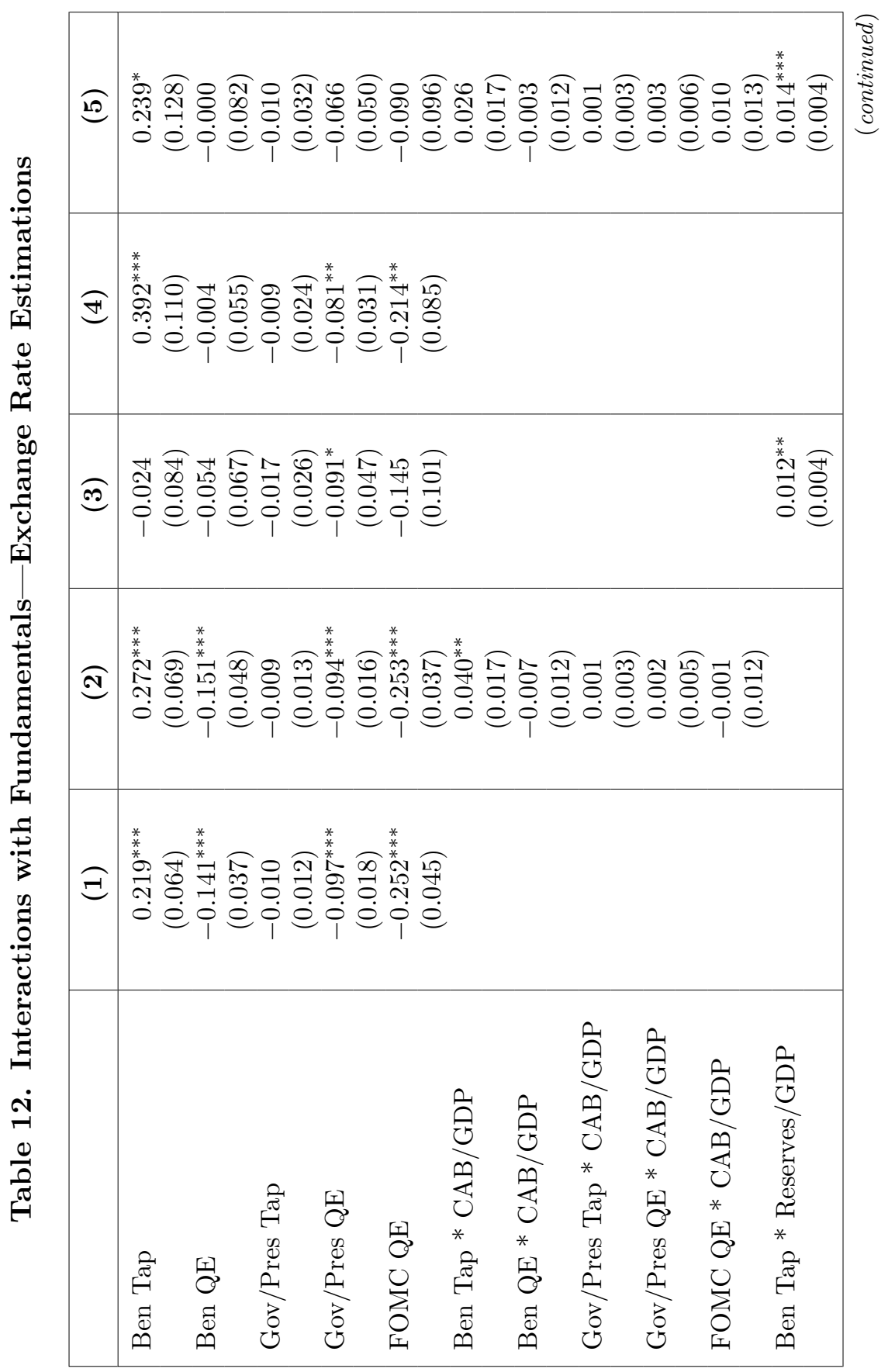




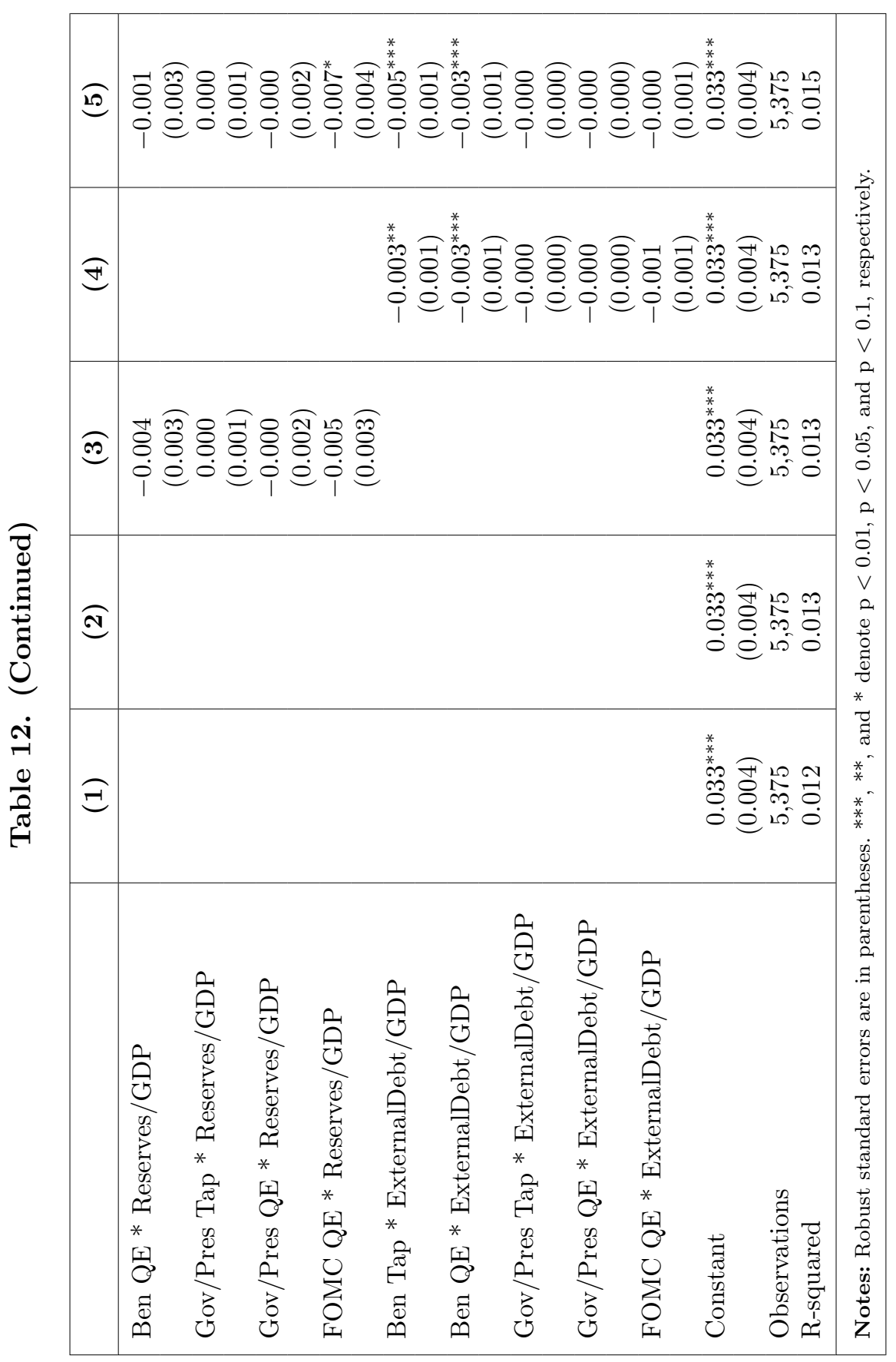


Table 13. Significance Test Results

\begin{tabular}{|l|c|c|c|c|}
\hline \multirow{2}{*}{} & \multicolumn{4}{|c|}{ Columns from Table 12} \\
\cline { 2 - 5 } & $\mathbf{( 2 )}$ & $\mathbf{( 3 )}$ & $\mathbf{( 4 )}$ & $\mathbf{5})$ \\
\hline Significance of Sum of the Coefficients & & & & \\
$\quad$ F-statistics & 15 & 0.02 & 12.64 & 4.04 \\
$\quad$ Prob $>$ F (p-value) & $(0.001)$ & $(0.883)$ & $(0.002)$ & $(0.056)$ \\
Joint Significance of the Coefficients & & & & \\
$\quad$ F-statistics & 7.76 & 7.84 & 6.94 & 12.39 \\
Prob $>$ F (p-value) & $(0.003)$ & $(0.002)$ & $(0.004)$ & $(0.000)$ \\
\hline
\end{tabular}

Notes: The table reports the significance test results for the Ben tapering and Ben tapering interaction with the fundamentals from table 12 , specifications $2-5$.

with stronger fundamentals are affected more by tapering (consistent with the earlier analysis), then we would expect a positive coefficient on BenTap $\times C A B / G D P$ (i.e., the larger the current account surplus, the larger is exchange rate depreciation associated with a Bernanke tapering announcement), a positive coefficient on BenTap $\times$ Reserves $/ G D P$ (i.e., the larger the level of reserves, the larger is exchange rate depreciation associated with a Bernanke tapering announcement), and a negative coefficient on BenTap $\times$ ExternalDebt/GDP (i.e., the larger the level of external debt, the less is exchange rate depreciation associated with a Bernanke tapering announcement).

Column 1 of table 12 reports the baseline results without interaction terms (as in table 3) for comparison purposes. Column 2 reports the interactions of tapering announcements with the current account $(C A B / G D P)$, column 3 reports interactions with reserves (Reserves/GDP), column 4 reports interactions with external debt (ExternalDebt/GDP), and column 5 combines the three sets of interaction terms into one regression.

Focusing on Bernanke's tapering announcements (BenTap) in columns 2-4, the results indicate that larger current account surpluses are associated with greater exchange rate deprecation (coefficient of 0.040), larger reserves are associated with greater exchange rate depreciation (0.012), and high external debt is associated with 
less exchange rate depreciation. It is useful to calculate the estimated effect for the robust and fragile groups using mean and median values (for each group) of the fundamentals. The estimated impact on exchange rates from BenTap for a country with a mean "robust" ("fragile") current account is 0.37 (0.14), for reserves is $0.37(0.16)$, and for external debt is $0.26(0.25)$. The same basic results hold up in the combined regression (column 5), with the exception of the interaction term with current account balances.

The bulk of these results are therefore consistent with our earlier results, i.e., countries with stronger fundamentals appear to be more affected by tapering announcements.

\subsection{Excluding Bernanke's May 22 Tapering Announcement}

A natural question that arises is whether the Bernanke tapering results are entirely driven by the market shock of the May 22 announcement. To address this issue, we reestimate the basic models estimated in table 3 with the modification that the Bernanke tapering announcements exclude the May 22 observation. Interestingly, the effect of the Bernanke tapering announcements excluding May 22 is greater on equity markets (an estimated coefficient of -0.416 , compared with -0.327 in table 3 ) but less on exchange rate depreciation (0.116, and not statistically significant, compared with 0.219 ). The effect on CDS spreads remains insignificant. The impact of the other announcements (e.g., other tapering and QE) is not affected by excluding Bernanke's May 22 tapering statement.

\subsection{Individual Country Effects}

We estimated our models with country fixed effects and in several formulations divided the sample into fragile and robust economies. This subsection shows the effects of tapering announcements by individual countries. In particular, in table 14, we show the effects of Bernanke's tapering announcements and governors'/ presidents' tapering announcements on asset prices for individual countries. In the table we report the sum of the common tapering event coefficient $\beta_{1}$ from $\beta_{1} \times$ Ben Tap $p_{t}$ (or $\beta_{3}$ from $\beta_{3} \times$ GovPres Tap $_{t}$ ) and the coefficient of the interaction term from Ben $T_{t}$ (GovPres Tapt) and the country-specific dummy variable. 


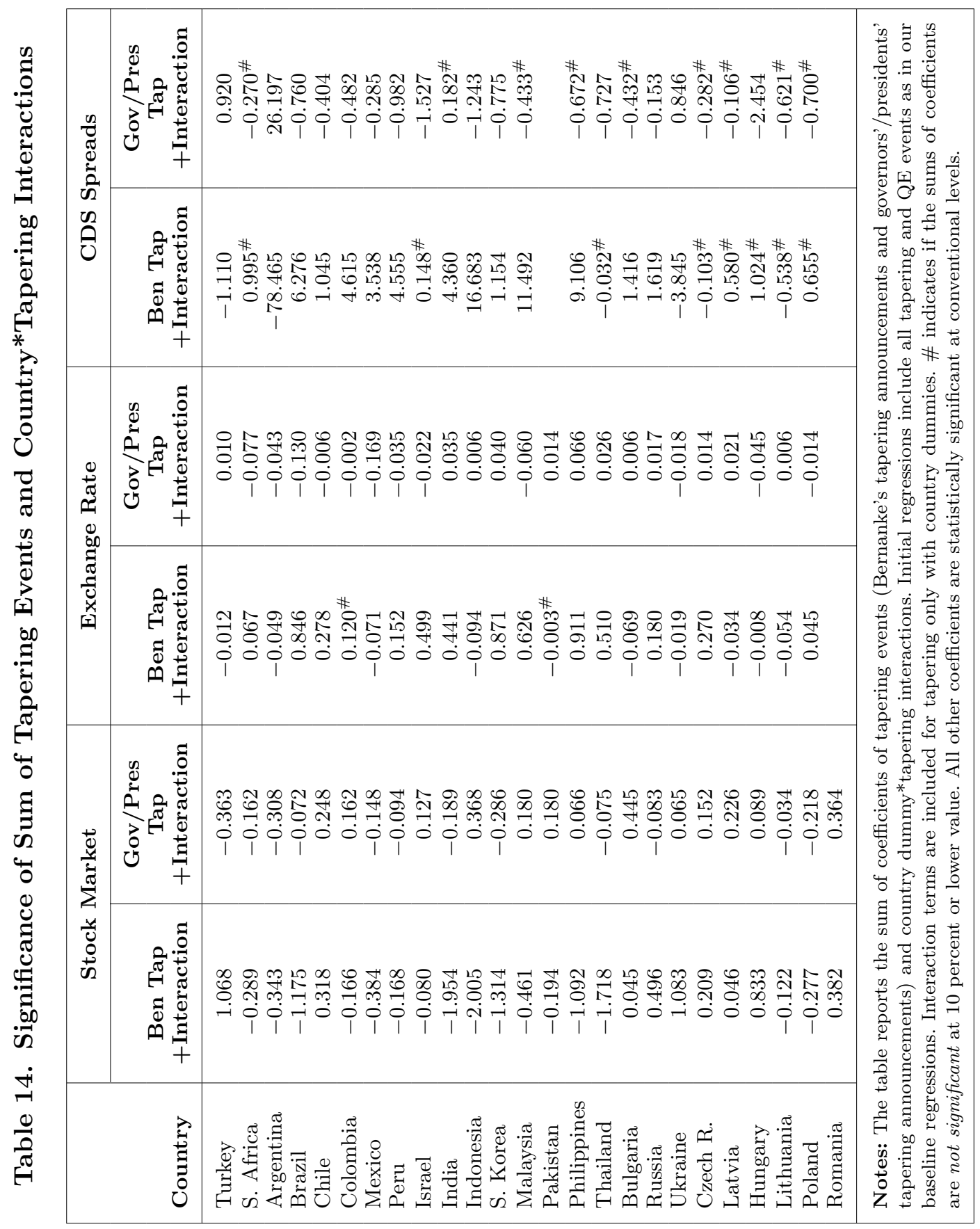


This measures the effect of tapering on a particular country. (All responses are statistically significant at the 10 percent level or higher unless indicated.)

The results reported in table 14 show substantial diversity of response across countries. For example, Bernanke's tapering announcements are associated with decreases (increases) in stock prices in sixteen of twenty-five (nine of twenty-five) cases, and all responses are statistically significant. While the results for the full sample indicate an average response of -0.327 to Bernanke's tapering announcements (table 3 ), the average response of the countries experiencing declines (increases) in stock prices is -0.734 (0.498). Similarly, Bernanke's tapering announcements are associated with depreciating currencies in fourteen of twenty-four countries, and with appreciating currencies in ten of twenty-four countries. Again the results are consistent with the full-sample response (0.219) reported in table 3 - the average response of the fourteen depreciating countries in table 14 is 0.438 , compared with an average response of -0.046 for the ten appreciating countries.

\section{Concluding Remarks}

Chairman Bernanke's tapering news had large effects on emerging markets, resulting in substantial drops in stock market indices and large exchange rate depreciations. This indicates the expectation of reduced capital inflows and carry-trade activity to emerging markets, with less investment in equity markets. By contrast, numerous and frequently quite vigorous statements in support of tapering by Federal Reserve presidents had little discernible effect on emerging-market financial prices - equities, exchange rates, CDS spreads - during our sample period. This may be because one of the Federal Reserve presidents - Fisher of the Federal Reserve Bank of Dallas - made many public statements advocating tapering (nine of our twenty-six events) that may have been discounted by financial markets due to the frequency and predictability of the message. QE statements by governors/presidents were associated with significant exchange rate appreciation, however, as were statements by Bernanke and the FOMC in favor of continuing the program. Statements in support of continuing QE were across a broad spectrum of Federal Reserve governors (including Vice Chair Yellen) and 
Federal Reserve Bank presidents during our sample period, perhaps accounting for the strong impact on the markets.

Our analysis also identified strong and systematic heterogeneity of adjustment to Federal Reserve tapering (and QE) news across emerging markets. The initial impact of Chairman Bernanke's tapering news had the largest effect on exchange rates in the emerging markets that had robust/strong international positions (i.e., current account surpluses, low foreign debt, high international reserves) or had more developed financial sectors. Tapering news by Federal Reserve presidents had little or no discernible impact on exchange rates regardless of whether they were classified as robust/weak in a combination of fundamentals, had current account surpluses or deficits, had high/low international reserves, or had low/high external debt. However, when we considered the differential impact of announcements on cumulative asset price changes over twenty-one business days (approximately one month), the effect of Bernanke's tapering news on fragile economies is (i) somewhat larger on equity prices than in robust economies; (ii) very similar to robust economies on exchange rate depreciation; and (iii) much greater (twice the average cumulative increase) on CDS spreads than in robust economies.

In terms of the dynamics of financial markets in robust and fragile economies, it appears that emerging markets with more fragile international positions were also affected, especially the "Fragile Five," over periods extending beyond the initial effects of Federal Reserve tapering announcements. These results suggest that, in the era of financial globalization, emerging-market financial markets are not insulated from expected changes in the Federal Reserve's policy stance, although it is sensitive to the heterogeneity among countries (Powell 2013 and Nechio 2014). The factors accounting for the timing and the intensity of market reactions deserve further exploration. The greater impact of Federal Reserve news on the robust emerging markets may be explained by anticipated balance sheet adjustments, where the size of positions and the liquidity of markets play a role (Eichengreen and Gupta 2014). Alternatively, market attention may shift over time from the short-run adjustment of positions to the reassessment of the greater adjustment challenges facing the fragile countries to the post-tapering world (Mondria, Wu, and Chang 2010 and Sims 2010). Investigating the possible linkages between faster 
price adjustment and less volatile future growth patterns is left for future research.

\section{References}

Ahmed, A., and A. Zlate. 2013. "Capital Flows to Emerging Market Economies: A Brave New World?" International Finance Discussion Paper No. 1081, Board of Governors of the Federal Reserve System.

Aizenman, J., M. Binici, and M. Hutchison. 2013. "Credit Ratings and the Pricing of Sovereign Debt during the Euro Crisis." Oxford Review of Economic Policy 29 (3): 582-609.

Aizenman, J., M. Hutchison, and Y. Jinjarak. 2013. "What Is the Risk of European Sovereign Debt Defaults? Fiscal Space, CDS Spreads and Market Pricing of Risk." Journal of International Money and Finance 34 (1): 37-59.

Caruana, J. 2012. "International Monetary Policy Interactions: Challenges and Prospects." Speech given at the CEMLASEACEN conference, Punta del Este, Uruguay, November 16.

Dooley, M., and M. Hutchison. 2009. "Transmission of the U.S. Subprime Crisis to Emerging Markets: Evidence on the DecouplingRecoupling Hypothesis." Journal of International Money and Finance 28 (8): 1331-49.

Eichengreen, B., and P. Gupta. 2014. "Tapering Talk: The Impact of Expectations of Reduced Federal Reserve Security Purchases on Emerging Markets."Policy Research Working Paper No. 6754, World Bank.

Mohanty, M. S. 2014. "The Transmission of Unconventional Monetary Policy to the Emerging Markets - An Overview." BIS Paper No. 78.

Mondria, J., T. Wu, and Y. Zhang, 2010 "The Determinants of International Investment and Attention Allocation: Using Internet Search Query Data." Journal of International Economics 82 (1): 85-95.

Nechio, F. 2014. "Fed Tapering News and Emerging Markets." Economic Letter (Federal Reserve Bank of San Francisco) 2014-06 (March 3).

Powell, J. 2013. "Advanced Economy Monetary Policy and Emerging Market Economies." Speech at the Federal Reserve Bank 
of San Francisco's 2013 Asia Economic Policy Conference, San Francisco, California, November 4.

Sims, C. A. 2010. "Rational Inattention and Monetary Economics." In Handbook of Monetary Economics, Edition 1, Vol. 3, ed. B. M. Friedman and M. Woodford, 155-81 (chapter 4). Elsevier.

Williams, C. J. 2011. "Unconventional Monetary Policy: Lessons from the Past Three Years." Economic Letter (Federal Reserve Bank of San Francisco) 2011-31 (October 3). . 2012. "Monetary Policy, Money, and Inflation." Economic Letter (Federal Reserve Bank of San Francisco) 2012-21 (July 9). 